\title{
Entrepreneurial Preferences Regarding Centralization
}

\author{
David D. Van Fleet \\ $\&$ \\ Roger W. Hutt \\ Arizona State University
}

\begin{abstract}
Author Note
The authors wish to thank Drs. John E. Butler, Frank Hoy, and Ella W. Van Fleet for their helpful comments on earlier drafts.
\end{abstract}

\begin{abstract}
The purpose of this paper is to present the results of a pilot study examining the extent to which preferences for decentralized organizational structures and entrepreneurship may be associated. Building upon the extant literature, relationships between level of education and a preference for centralization and between work experience and a preference for decentralization are analyzed. Also studied is the preference for centralization/decentralization according to demographic factors as well as how individuals perceive their readiness for and knowledge about entrepreneurship. A survey of students and non-students enabled comparisons across a range of ages and years of education. Regardless of whether they were categorized as employees, managers, or business owners, respondents with fewer years of education indicated a greater preference for centralization. Similarly, regardless of category, respondents with fewer years of work experience preferred centralization. Finally, those believing they were knowledgeable about and ready for entrepreneurship showed a greater preference for decentralization. Findings cannot be generalized due to the small, non-random convenience sample and the comparisons of small subsets of data. Lessons learned in the study and the increased understanding of attitudes regarding centralization/decentralization, however, may lead to new and useful concepts for entrepreneurship education and in forming entrepreneurial teams within organizations.
\end{abstract}

Keywords: centralization, decentralization, organizational structure, entrepreneurial policy, education, students

\section{Background}

When power and authority are CENTRALIZED, important decisions generally are made by higher-level managers and passed down to lower levels. This tends to result in more managerial layers in the organization but less duplication of actual work and in procedures that 
are uniform and easier to control. Decision making is relatively rapid and there is strong control of actions, strategy, and risk. On the other hand, top managers may be out of touch with needs at the lower levels, vertical communication can be slow and cumbersome, and lower-level employees may have reduced motivation (this paragraph based on Carpenter, Bauer, \& Erdogan, 2010, p.184; Griffin, 2011, p.352; Lunenburg, 2012; Van Fleet \& Peterson, 1994, pp. 253-254).

When power and authority are DECENTRALIZED, important decisions generally are made not by higher-level managers but by middle-level and supervisory-level managers or other employees who will be responsible for implementing them. This tends to reduce layers in the organization and encourages those individuals to solve their own problems. Thus, decisions are made more quickly thereby increasing the organization's flexibility and efficiency, communication may be faster, and lower-level employees may have increased motivation (this paragraph based on Carpenter, Bauer, \& Erdogan, 2010, p.184; Griffin, 2011, p. 352; Lunenburg, 2012; Van Fleet \& Peterson, 1994, pp. 253-254).

\section{Introduction}

Organizations have long debated whether centralized or decentralized structural arrangements are best for organizing entrepreneurship policy (Nielsen, 2016; Pedersen, Zachariassen, \& Arlbjørn, 2012; Andrews, Boyne, Law \& Walker, 2009; Stiglitz \& Sah, 1991). Centralization is seen as important where conflict resolution is important (Sheremata, 2000). It can also enhance time efficiency (Boureois \& Eisenhardt, 1988). Decentralization, on the other hand, seems best when motivation and creativity are important in dealing with complex situations (Malone, 2004; Herron \& Robinson, 1993; Shaw, 1964). Indeed, this seems to have been a major factor underlying changes in military structural arrangements during the Iraq war (McChrystal, Collins, Silverman, \& Fussell, 2015). Large, mature organizations have become largely decentralized (Wulf, 2012; Harris \& Raviv, 2005), but many have raised the question of whether or not to recentralize (Wulf, 2012; Johnson, 2011; Von Simson, 1990). Recentralizing, it has been suggested, is only appropriate under certain conditions. Those include when only a few individuals have the information necessary for making decisions; when it is critical to have a single vision; and when conflict resolution is critical (Malone, 2004). Those conditions have also been framed as questions: Is centralization mandated? Does centralization add significant value? Are the risks low? (Campbell, Kunisch, \& Müller-Stewens, 2011). But in particular, for small and medium sized entrepreneurial endeavors, such simple dictums seem questionable (Nielsen, 2016). Newly established organizations tend to be centralized but become more decentralized as they grow (Harris \& Raviv, 2005; Hutt, 1993).

Just as with those newly established organizations, in academic environments when students form or are put into groups, they seem to migrate toward more centralized approaches. They do this even though such groups may perform worse on projects and receive lower project grades (Berdahl \& Anderson, 2005; Mohammad-Zadeh, 2002). This tendency toward centralization may exist because students are not aware that it leads to lower performance, or they may perceive the project as relatively simple, or they simply assume that this is the way to finish faster (Berdahl \& Anderson, 2005; Shaw, 1964). While there is some evidence regarding characteristics of students who might start their own organizations (Pour, Nooriaee, \& Heydan, 2013; Hutt \& Van Hook, 1986), little seems to be known about student predilections for 
centralized or decentralized organizational arrangements (Wagner \& Van Dyne, 1999). Understanding such predilections is important first because an orientation toward decentralization has been shown to be positively associated with small and medium sized entrepreneur organizations (Zahra, Hayton, \& Salvato, 2004) and second because attitudes regarding centralization/decentralization may be important in forming entrepreneurial teams within larger organizations (Forbes, Borchert, Zellmer-Bruhn, \& Sapienza, 2006). The purpose of this study was to take a first step toward providing that information.

\section{Hypotheses}

These studies seem to suggest that experienced managers may have different preferences toward centralization or decentralization. But will experience suggest more centralization (Achcaoucaou, Bernardo, \& Castan, 2009; Hollenbeck, 2000) or more decentralization (Nienhueser \& Hossfeld, 2011)? It seems that the latter is the case; however, Aghion, Bloom, and Van Reenen (2014) suggest that learning or education is more important than experience. Thus, the following Hypotheses are suggested:

Hypothesis 1: The more experience one has, the greater the preference will be for decentralization.

Hypothesis 2: The less formal education one has, the greater the preference will be for centralization.

Spors (2009) suggested several questions by which an individual could assess if he or she is ready to pursue entrepreneurship. To obtain some indication of respondents' interest in and willingness to pursue entrepreneurship, we adapted Spors' questions to derive an Entrepreneurial Readiness score (while not validated, these seem appropriate for this pilot study; see Results for details; Cronbach's alpha 0.8669; split-half correlation 0.7591). Shane (2008) also suggested several issues of which individuals need to be aware if they are to succeed as entrepreneurs. So, to obtain an indication of the respondent's awareness of some important issues regarding entrepreneurs, we adapted Shane's issues to derive an Entrepreneurship Knowledge score (while not validated, these seem appropriate for this pilot study; see Results for details; Cronbach's alpha 0.4848; split-half correlation 0.5853). The issues raised in those papers suggest the following Hypotheses:

Hypothesis 3: The greater one's Entrepreneurial Readiness, the greater the preference will be for decentralization.

Hypothesis 4: The greater one's Entrepreneurial Knowledge, the greater the preference will be for decentralization.

\section{Method}

To identify such predilections an online survey using SurveyMonkey was conducted with a wide range of student and non-student respondents for comparative purposes. While 117 individuals responded to the survey, three were incomplete and dropped. Basic demographic 
information for the remaining 114 respondents is shown in Table 1 . The average age of the respondents (47.7) is greater than that of typical undergraduates. Almost half $(48.6 \%)$ of the respondents had bachelor's degrees $(19.8 \%)$ or less $(28.8 \%)$. This distribution provided the opportunity to compare respondents with bachelor's degrees or less (mostly undergraduates) with respondents having more (mostly far more) education. While there was little diversity among some characteristics (e.g., gender, race, language spoken at home, employment), there were diverse responses for other factors (ZIP codes from 32 states, religion, experience). In addition to usual demographic information, Entrepreneurial Readiness and Entrepreneurial Knowledge scores were obtained. Finally, three conditions were included to see if preferences might vary according to those different circumstances: working for the organization, managing within the organization, and owning the organization.

Table 1.

Respondent Characteristics $(n=114)$

\begin{tabular}{|c|c|}
\hline Age & $\begin{array}{c}19 \text { to } 87 \text { years } \\
47.7 \text { average }\end{array}$ \\
\hline Gender & 76 males 38 females \\
\hline Race & 98 White/Caucasian 16 others \\
\hline Education & 54 bachelor's degree or less \\
58 beyond a bachelor's degree
\end{tabular}

\section{Results}

As noted earlier, an Entrepreneurial Readiness score was derived based on the work of Spors (2009). That score provided an indicator of each respondent's enthusiasm and preparation for becoming an entrepreneur (Table 2). Scale items were 0, 1, 2, 3, 4 for each of the 18 questions having five choices. For Yes-No questions, each Yes was 4 points, for a total possible score of 72. Scores ranged from 2 to 68 with a mean of 43.75 (Cronbach's alpha 0.8669; splithalf correlation 0.7591 ). 


\section{Table 2.}

\section{Entrepreneurial Readiness Items}

\begin{tabular}{|c|c|}
\hline Are you a self-starter? & 95 yes 19 no \\
\hline $\begin{array}{l}\text { Do you currently have a business idea, concept, or plan that you're } \\
\text { passionate about? }\end{array}$ & 54 yes 60 no \\
\hline Will you have a partner with whom you will or may start a business venture? & 41 yes 73 no \\
\hline How interested are you in starting something totally new? & $\begin{array}{l}24 \text { no interest } \\
22 \text { a little interest } \\
19 \text { some interest } \\
26 \text { quite interested } \\
23 \text { extremely interested }\end{array}$ \\
\hline How interested are you in owning a franchise? & $\begin{array}{l}68 \text { no interest } \\
20 \text { a little interest } \\
15 \text { some interest } \\
7 \text { quite interested } \\
4 \text { extremely interested }\end{array}$ \\
\hline $\begin{array}{l}\text { How likely is it that you will start a business (or other venture, such as a } \\
\text { non-profit), sometime in your life? [or start another business if you have } \\
\text { already stated one] }\end{array}$ & $\begin{array}{l}34 \text { highly unlikely } \\
10 \text { somewhat unlikely } \\
16 \text { who knows? } \\
18 \text { somewhat likely } \\
26 \text { highly likely }\end{array}$ \\
\hline Are you willing and able to bear great financial risk? & \begin{tabular}{|l}
22 unable to take any risk \\
28 able to take a little risk \\
39 able to take some risk \\
18 able to take a sizeable risk \\
7 able to take great risk \\
\end{tabular} \\
\hline $\begin{array}{l}\text { Are you willing to sacrifice your lifestyle for potentially several years } \\
\text { (during startup)? }\end{array}$ & $\begin{array}{l}57 \text { yes } \\
55 \text { no } \\
\end{array}$ \\
\hline If you attempt to start a business, will your "significant other" be on board? & 59 yes 18 no 36 not applicable \\
\hline $\begin{array}{l}\text { Are you or would you be comfortable having responsibility: } \\
\text { for all aspects of running a business? } \\
\text { for the financial aspects of running a business? } \\
\text { for hiring/firing and supervising personnel? } \\
\text { for handling sales/marketing activities in running a business? } \\
\text { for handling customer problems in running a business? } \\
\text { for the success or failure of a business? } \\
\text { for making quick decisions with little or no information? }\end{array}$ & $\begin{array}{r}81 \text { yes; } 32 \text { no } \\
85 \text { yes; } 28 \text { no } \\
92 \text { yes; } 21 \text { no } \\
87 \text { yes; } 26 \text { no } \\
101 \text { yes; } 12 \text { no } \\
95 \text { yes; } 18 \text { no } \\
85 \text { yes; } 27 \text { no }\end{array}$ \\
\hline What's your track record of executing your business ideas? & $\begin{array}{l}27 \text { have never tried } \\
8 \text { few of my ideas even succeed } \\
39 \text { some of my ideas succeed } \\
36 \text { most of my ideas succeed } \\
3 \text { able to put my ideas into practice }\end{array}$ \\
\hline How persuasive and well-spoken are you? & $\begin{array}{l}0 \text { I'm not persuasive at all } \\
10 \text { I'm not very persuasive } \\
33 \text { I do fairly well } \\
47 \text { I am generally persuasive } \\
22 \text { This is one of my strong } \\
\text { characteristics }\end{array}$ \\
\hline
\end{tabular}

Note: A few items reworded to fit the table. Scoring: Scale items were 0, 1, 2, 3, 4 for each of the 18 questions having five choices. For Yes-No questions, each Yes $=4$ points. Cronbach's alpha 0.8669; split-half correlation 0.7591 . 
Also noted earlier, an Entrepreneurship Knowledge score was derived based on the work of Shane (2008). That score provided an indicator of each respondent's knowledge or awareness of some important issues regarding entrepreneurs. All 10 items were identified as false and so were simply scored as one point for each correct response, for a total possible score of 10. Scores ranged from 2 to 10 correct, with a mean of 7.15 as shown in Table 3 (Cronbach's alpha 0.4848; split-half correlation 0.5853 ).

Table 3.

\section{Entrepreneurship Knowledge Items}

\begin{tabular}{|l|c|c|}
\hline & True & False \\
\hline It takes a lot of money to finance a new business. & 43 & 66 \\
\hline Venture capitalists are a good place to go for start-up money. & 31 & 79 \\
\hline Most business angels are rich. & 46 & 62 \\
\hline Start-ups can't be financed with debt. & 17 & 92 \\
\hline Banks don't lend money to start-ups. & 19 & 90 \\
\hline Most entrepreneurs start businesses in profitable or potentially profitable industries. & 50 & 58 \\
\hline The growth of a start-up depends more on an entrepreneur's talent than on the business. & 65 & 43 \\
\hline Most entrepreneurs become successful financially. & 10 & 98 \\
\hline Many start-ups achieve the sales growth projections that equity investors are looking for. & 14 & 95 \\
\hline Starting a business is easy. & 4 & 105 \\
\hline
\end{tabular}

Note: All 10 items were identified as false and were simply scored as one point for each correct response, for a total possible score of 10 . Cronbach's alpha 0.4848 ; split-half correlation 0.5853

To examine Hypothesis 1, the respondents were separated by years of experience. Since the mean (26.7) and the median (27.2) were nearly the same (see Table 1), a median split was used. Using t-tests, as shown in Table 4, a centralization preference difference was significant in two conditions: working for the organization and managing within the organization. But there was a greater preference for centralization by those with less experience in all three conditions: working for the organization, managing within the organization, owning the organization. Thus Hypothesis 1 is supported. In a similar manner, to examine Hypothesis 2, the respondents were separated by educational level. Using t-tests, as shown in Table 5, again a centralization preference difference was significant in the same two conditions and also a greater preference for centralization by those with less education in all three conditions: working for the organization, managing within the organization, owning the organization. Thus Hypothesis 2 is supported.

Noting the numerous other significant differences between these groups led to the question of what really seems to influence preferences for centralization versus decentralization. To examine that question, the respondents were separated into three groups by their preferences in the three conditions: working for the organization, managing within the organization, owning the organization (Table 6). While the Readiness score was not significant when education or experience categories were examined, it is significant when examining all three conditions, with those with higher Readiness scores preferring decentralization. Thus, Hypothesis 3 is supported. Knowledge scores were not significant when examining education but were for experience (those with more experience had significantly higher scores). However, Knowledge scores were not significant when examining all three conditions, so Hypothesis 4 is not supported. 
Table 4.

Experience Level Comparisons

\begin{tabular}{|c|c|c|}
\hline & $\begin{array}{c}\text { Less Experience } \\
(<27.2 ; \mathrm{n}=57)\end{array}$ & $\begin{array}{l}\text { More Experience } \\
(>27.2 ; n=57)\end{array}$ \\
\hline $\begin{array}{l}\text { Centralization Preference (\%) } \\
\text { Work for } \\
\text { Manage } \\
\text { Own }\end{array}$ & $\begin{array}{l}31.58 \\
\mathbf{3 8 . 6 0} \\
47.37\end{array}$ & $\begin{array}{r}* * \mathbf{1 4 . 0 4} \\
* * \mathbf{1 9 . 3 0} \\
36.84\end{array}$ \\
\hline \multicolumn{3}{|l|}{ Means Within Categories: } \\
\hline Mean Age & 32.58 & $* * * 62.82$ \\
\hline Experience (years) & 12.9 & $* * * 40.51$ \\
\hline Exper. in new/small business & 4.25 & $* * * 12.44$ \\
\hline Readiness Score & 45.04 & 42.46 \\
\hline Knowledge Score & 6.77 & $* * 7.51$ \\
\hline \multicolumn{3}{|l|}{ Percent's Within Categories: } \\
\hline$\%$ Male & 52.63 & $* * * 80.70$ \\
\hline$\%$ White & 78.95 & $* * 92.98$ \\
\hline$\%>\mathrm{BA} / \mathrm{BS}$ & 29.82 & $* * * 71.93$ \\
\hline$\%$ English spoken at home & 89.47 & 96.49 \\
\hline$\%$ Worked full-time in school & 89.47 & 91.23 \\
\hline$\%$ Started & 38.60 & $* * * 66.67$ \\
\hline$\%$ Relative & 84.21 & $* * 68.42$ \\
\hline$\%$ Currently employed full-time & 59.65 & 68.42 \\
\hline \multicolumn{3}{|l|}{ Religion (percent) } \\
\hline Christian Scientist & 5.26 & 3.51 \\
\hline Judaism & 3.51 & 8.77 \\
\hline Mormon & 3.51 & 1.75 \\
\hline Protestant & 14.04 & $* * * 38.60$ \\
\hline Roman Catholic & 21.05 & 14.04 \\
\hline Other/No Preference & 52.63 & $* * 33.33$ \\
\hline
\end{tabular}

$* \mathrm{p} \leq .10 * * \mathrm{p} \leq .05 * * * \mathrm{p} \leq .01$

A further examination of the data in Table 6 indicates that those who prefer centralization also tend to have less formal education, although based on t-tests that is significant for only one of the conditions (managing within the organization). Religion has been noted in prior research as having an influence (Pearce, Fritz, \& Davis, 2010); and religion does seem to play a role here most notably for Roman Catholics, who tended to prefer centralization in every condition. Decentralization, on the other hand, is preferred under all three conditions, with the level of preference decreasing as one moves from working for an organization to managing within the organization to owning it. Those who have started a business prefer decentralization if they work for or manage within the organization, but the difference is not significant if they are the owner. But what if the focus is on individuals who have actually started a business, the entrepreneurs? Might the entrepreneurial types show a tendency to prefer centralization versus decentralization? 
That comparison was made and the results presented in Table 7. Clearly, entrepreneurs prefer decentralization. The entrepreneurs also tend to be older, better educated, more experienced, and, not surprisingly, score higher on the Entrepreneurial Readiness questions.

Table 5.

Education Level Comparisons

\begin{tabular}{|c|c|c|}
\hline & $\begin{array}{c}\text { Bachelor's } \\
\text { degree or } \\
\text { less } \\
(n=54)\end{array}$ & $\begin{array}{l}\text { Greater than } \\
\text { bachelor's } \\
\text { degree } \\
(\mathrm{n}=58)\end{array}$ \\
\hline $\begin{array}{l}\text { Centralization Preference (\%) } \\
\text { Work for } \\
\text { Manage } \\
\text { Own } \\
\end{array}$ & $\begin{array}{l}\mathbf{2 1 . 2 8} \\
\mathbf{3 1 . 9 1} \\
42.55\end{array}$ & $\begin{array}{r}* * \mathbf{9 . 2 6} \\
* * \mathbf{1 2 . 9 6} \\
31.48\end{array}$ \\
\hline \multicolumn{3}{|l|}{ Means Within Categories: } \\
\hline Mean Age & 37.13 & $* * 56.66$ \\
\hline Experience (years) & 17.89 & $* * * 34.42$ \\
\hline Exper. in new/small business & 7.45 & 9.36 \\
\hline Readiness Score & 46.00 & 42.02 \\
\hline Knowledge Score & 6.82 & 7.45 \\
\hline \multicolumn{3}{|l|}{ Percent's Within Categories: } \\
\hline $\begin{array}{l}\% \text { Male } \\
\% \text { White } \\
\% \text { English spoken at home }\end{array}$ & $\begin{array}{l}\mathbf{5 5 . 5 6} \\
81.48 \\
\mathbf{9 8 . 1 5}\end{array}$ & $\begin{array}{r}* * 77.59 \\
89.66 \\
* * 87.93\end{array}$ \\
\hline$\%$ Worked full-time in school & 87.04 & 93.10 \\
\hline$\%$ Started & 42.59 & $* * 63.79$ \\
\hline$\%$ Relative & 77.78 & 74.14 \\
\hline$\%$ Currently employed full-time & 51.85 & $* * * 77.59$ \\
\hline \multicolumn{3}{|l|}{ Religion (percent) } \\
\hline Christian Scientist & 9.26 & $* * 0.00$ \\
\hline Judaism & 3.70 & 8.62 \\
\hline Mormon & 1.85 & 3.45 \\
\hline Protestant & 14.81 & $* * * 36.21$ \\
\hline Roman Catholic & 18.52 & 17.24 \\
\hline Other/No Preference & $\mathbf{5 1 . 8 5}$ & $* * 34.48$ \\
\hline
\end{tabular}

$* \mathrm{p} \leq .10 * * \mathrm{p} \leq .05 * * * \mathrm{p} \leq .01$ 
Table 6.

Centralization versus Decentralization Comparisons

\begin{tabular}{|c|c|c|c|c|c|c|}
\hline & \multicolumn{2}{|c|}{ Work For } & \multicolumn{2}{|c|}{ Manage } & \multicolumn{2}{|c|}{ Own } \\
\hline & $\begin{array}{l}\text { Central } \\
(\mathrm{n}=15)\end{array}$ & $\begin{array}{c}\text { Decentral } \\
(\mathrm{n}=88)\end{array}$ & $\begin{array}{l}\text { Central } \\
(\mathrm{n}=22)\end{array}$ & $\begin{array}{c}\text { Decentral } \\
(\mathrm{n}=81)\end{array}$ & $\begin{array}{l}\text { Central } \\
(\mathrm{n}=37)\end{array}$ & $\begin{array}{c}\text { Decentral } \\
(\mathrm{n}=66)\end{array}$ \\
\hline Prefer (\% across respondents) $\rightarrow$ & 14.56 & $* * * 85.44$ & 21.36 & $* * * 78.64$ & 35.92 & $* * * 64.08$ \\
\hline \multicolumn{7}{|l|}{ Means Within Categories: } \\
\hline Age & 47.60 & 47.70 & 46.95 & 47.89 & 49.05 & 46.92 \\
\hline Experience (years) & 23.60 & 27.31 & 24.98 & 27.26 & 28.77 & 26.35 \\
\hline Exper. in new/small bus. (yrs.) & 8.20 & 8.30 & 8.32 & 8.27 & 9.68 & 7.41 \\
\hline Readiness Score & 36.20 & $* 45.27$ & 39.59 & $* 45.25$ & 43.27 & $* 45.61$ \\
\hline Knowledge Score & 6.73 & 7.26 & 6.95 & 7.26 & 7.09 & 7.23 \\
\hline \multicolumn{7}{|l|}{ percent Within Categories: } \\
\hline$\%$ Male & 40.00 & $* * 72.73$ & 54.55 & 71.60 & 67.57 & 68.18 \\
\hline$\%$ White & 73.33 & 87.50 & 81.82 & 86.42 & 89.19 & 83.33 \\
\hline$\%>\mathrm{BA} / \mathrm{BS}$ & 33.33 & 55.68 & 27.27 & $* * 56.82$ & 45.95 & 56.06 \\
\hline \% English spoken at home & 86.67 & 94.32 & 90.91 & 93.83 & 94.59 & 92.42 \\
\hline$\%$ Worked full-time in school & 80.00 & 92.05 & 86.36 & 91.36 & 97.30 & $* 86.36$ \\
\hline$\%$ Started & 20.00 & $* * * 56.82$ & 31.82 & $* * 56.79$ & 40.54 & 57.58 \\
\hline$\%$ Relative & 73.33 & 79.55 & 77.27 & 79.01 & 70.27 & 83.33 \\
\hline \% Currently employed full-time & 53.33 & 68.18 & 63.64 & 66.67 & 67.57 & 65.15 \\
\hline \multicolumn{7}{|l|}{ Religion: } \\
\hline \%Christian Scientist & 13.33 & $* 3.41$ & 9.09 & 3.70 & 5.41 & 4.55 \\
\hline \%Judaism & 0.00 & 6.82 & 0.00 & 7.41 & $\mathbf{0 . 0 0}$ & $* 9.09$ \\
\hline \%Mormon & 0.00 & 3.41 & 0.00 & 3.70 & 0.00 & 4.55 \\
\hline$\%$ Protestant & 20.00 & 28.41 & 22.73 & 28.40 & 32.43 & 24.24 \\
\hline$\%$ Roman Catholic & 40.00 & $* * 14.77$ & 36.36 & $* * 13.58$ & 27.03 & $* 13.64$ \\
\hline$\%$ Other/No Preference & 26.67 & 43.18 & 31.82 & 43.21 & 35.13 & 43.93 \\
\hline
\end{tabular}

$* p \leq .10 * * p \leq .05 * * * p \leq .01$ 
Table 7.

Start-up Experience Comparisons

\begin{tabular}{|c|c|c|}
\hline & $\begin{array}{c}\text { Never } \\
\text { Started a } \\
\text { Business } \\
(\mathrm{n}=54)\end{array}$ & $\begin{array}{c}\text { Have } \\
\text { Started a } \\
\text { Business } \\
(\mathrm{n}=60)\end{array}$ \\
\hline $\begin{array}{l}\text { Centralization Preference }(\%) \\
\text { Work for } \\
\text { Manage } \\
\text { Own }\end{array}$ & $\begin{array}{l}22.22 \\
27.78 \\
40.74 \\
\end{array}$ & $\begin{array}{r}* * * 5.00 \\
* * 11.67 \\
* 25.00\end{array}$ \\
\hline \multicolumn{3}{|l|}{ Means Within Categories: } \\
\hline Mean Age & 44.93 & $* 50.20$ \\
\hline Experience (years) & 22.78 & $* * 30.24$ \\
\hline Exper. in new/small business & 4.33 & $* * * 11.96$ \\
\hline Readiness Score & 37.61 & $* * * 49.27$ \\
\hline Knowledge Score & 7.02 & 7.27 \\
\hline \multicolumn{3}{|l|}{ Percent's Within Categories: } \\
\hline$\%$ Male & 55.56 & $* * 76.67$ \\
\hline$\%$ White & 87.04 & 85.00 \\
\hline$\%>\mathrm{BA} / \mathrm{BS}$ & 38.89 & $* * 61.67$ \\
\hline$\%$ English spoken at home & 94.44 & 91.67 \\
\hline$\%$ Worked full-time in school & 85.19 & $* 95.00$ \\
\hline$\%$ Relative & 70.37 & 81.67 \\
\hline$\%$ Currently employed full-time & 61.11 & 66.67 \\
\hline \multicolumn{3}{|l|}{ Religion (percent) } \\
\hline Christian Scientist & 1.85 & 6.67 \\
\hline Judaism & 1.85 & $* 10.00$ \\
\hline Mormon & $\mathbf{0 . 0 0}$ & $* 5.00$ \\
\hline Protestant & 25.93 & 26.67 \\
\hline Roman Catholic & 24.07 & $* 11.67$ \\
\hline Other/No Preference & 46.30 & 40.00 \\
\hline
\end{tabular}

$* \mathrm{p} \leq .10 * * \mathrm{p} \leq .05 * * * \mathrm{p} \leq .01$

\section{Discussion}

In interpreting the data collected and analyzed in this study it would have been helpful to consider whether respondents' perspectives differ and change as their work experience changes. For instance, consider responses for the number of years of experience in a new/small business. An argument could be made that an employee with an entrepreneurial inclination (i.e., perspective) would prefer a decentralized structure when serving as an employee. The term "selfstarter" is often applied to such an individual, and employees who thrive in such an environment are said to be empowered. Continuing this line of thinking, when serving in a managerial role, the same person may have a different preference; for example, the manager might prefer decentralization of decision-making in the management ranks at his or her level and above but be 
less supportive (if at all) of extending the same latitude to those at lower levels. On the other hand, the extent of an owner's preference for decentralization might result from a desire for personal decision-making freedom (after all, he or she chose to be an owner/entrepreneur) that does not extend to the rest of the organization. This seems to be the general pattern of responses across the various categories.

\section{Limitations and Recommendations for Future Research}

These results suggest that further research on the topic is warranted, including a more carefully-focused sample. The use of social networking to obtain respondents resulted in a nonrandom, convenience sample. A more carefully-focused sample representing a carefully designed population may also have yielded more meaningful separate categories. While the reliability of the readiness measure was acceptable, that of the knowledge measure was not. So improved readiness and knowledge measures would also be useful for future research. Also, attention should also be given to the respondents' work history to determine the relationship of managerial position to preference regarding centralization.

\section{Conclusion}

Programs for nascent entrepreneurs (e.g., those learning about entrepreneurship on their own or in entrepreneurship and/or small business classes; Harrington \& Maysami, 2015) should make every effort to help them understand the advantages and disadvantages of centralization and decentralization and their impact on policy. The courses should also emphasize the contingency nature of organizational arrangements, such as which functions may or may not be best centralized at a particular point in time. Such improvements in entrepreneurial education could foster more entrepreneurial success.

\section{References}

Achcaoucaou, F., Bernardo, M., \& Castan, J. M. (2009). Determinants of organisational structures: An empirical study. Review of International Comparative Management, 10(3), 566-577.

Aghion, P., Bloom, N., \& Van Reenen, J. (2014). Incomplete contracts and the internal organization of firms. Journal of Law, Economics and Organization, 30(1), i37-i63.

Andrews, R., Boyne, G. A., Law, J., \& Walker, R. M. (2009). Centralization, organizational strategy, and public service performance. Journal of Public Administration Research and Theory, 19(1), 57-80.

Berdahl, J. L., \& Anderson, C. (2005). Men, women, and leadership centralization in groups over time. Group Dynamics: Theory, Research, and Practice, 9(1), 45-57.

Bourgeois, L. J., III, \& Eisenhardt, K. M. (1988). Strategic decision processes in high velocity environments: Four cases in the microcomputer industry. Management Science, 34(7), 816-835.

Campbell, A., Kunisch, S., \& Müller-Stewens, G. (2011). To centralize or not to centralize? McKinsey Quarterly, 2011(3), 97-102.

Carpenter, M., Bauer, Y., \& Erdogan, B. (2010). Principles of management 1.1. Irvington, NY: Flat World Knowledge. 
Forbes, D. P., Borchert, P. S., Zellmer-Bruhn, M. E., \& Sapienza, H. J. (2006). Entrepreneurial team formation: An exploration of new member addition, Entrepreneurship Theory and Practice, 30(2), 225-248.

Griffin, R. W. (2011) Management (10th ed.). Mason, OH: South-Western Cengage Learning. Harrington, C., \& Maysami, R. (2015). Entrepreneurship education and the role of the regional university. Journal of Entrepreneurship Education, 18(2), 29-38.

Harris, M., \& Raviv, A. (2005). Allocation of decision-making authority. Review of Finance, 9(3), 353-383.

Herron, L., \& Robinson, R. B., Jr. (1993). A structural model of the effects of entrepreneurial characteristics on venture performance. Journal of Business Venturing, 8(3), 281-294.

Hollenbeck, J. (2000). A structural approach to external and internal person team fit. Applied Psychology: An International Review, 49(3), 534-549.

Hutt, R. W. (1993). Entrepreneurship: Starting your own business (3rd ed.). Cincinnati: SouthWestern Publishing Company.

Hutt, R. W., \& Van Hook, B. L. (1986). Students planning entrepreneurial careers and students not planning entrepreneurial careers: A comparative analysis. In Frontiers of entrepreneurship research: Proceedings of the sixth annual Babson College entrepreneurship research conference (pp. 223-224). Babson College, Wellesley, MA.

Johnson, B. (2011). Business intelligence should be centralized. International Journal of Business Intelligence Research, 2(4), 42-54.

Lunenburg, F. C. (2012). Organizational structure: Mintzberg's framework. International Journal of Scholarly, Academic, Intellectual Diversity, 14(1), 1-8.

Malone, T. W. (2004). The future of work: How the new order of business will shape your organization, your management style, and your life. Boston: Harvard Business School Press.

Mohammad-Zadeh, S. (2002). A study of the correlation between centralization attributes and team failure (Unpublished doctoral dissertation). The University of Alabama at Huntsville.

Nielsen, P. S. (2016). An organizational taxonomy of entrepreneurship policy delivery structures. Journal of Small Business and Enterprise Development, 23(2), 514-527.

Nienhueser, W., \& Hossfeld, H. (2011). The effects of trust on the preference for decentralized bargaining. Thousand Oaks, CA: SAGE Open.

Pearce, J. A., III, Fritz, D. A., \& Davis, P. S. (2010). Entrepreneurial orientation and the performance of religious congregations as predicted by rational choice theory. Entrepreneurship Theory and Practice, 34(1), 219-248.

Pedersen, S. G., Zachariassen, F., \& Arlbjørn, J. S. (2012). Centralisation vs de-centralisation of warehousing. Journal of Small Business and Enterprise Development, 19(2), 352-369.

Pour M. S., Nooriaee, M. H., \& Heydan, J. (2013). University students' entrepreneurial intention: Perceptions of commerce students at Tehran Region. Procedia-Social and Behavioral Sciences, 93(21), 1805-1810.

Shane, S. (2008). Top ten myths of entrepreneurship. Retrieved from http:/guykawasaki.com/top-ten-myths-o/

Shaw, M. E. (1964). Communication networks. In L. Berkowitz (Ed.), Advances in experimental social psychology (pp. 111-147). New York: Academic Press.

Sheremata, W. A. (2000). Centrifugal and centripetal forces in radical new product development under time pressure. Academy of Management Review, 25(2), 389-408. 
Spors, K. K. (2009). So you want to be an entrepreneur. Wall Street Journal (Eastern edition), R.1.

Stiglitz, J. E., \& Sah, R. K. (1991). The quality of managers in centralized versus decentralized organizations. Quarterly Journal of Economics, 106, 289-295.

Van Fleet, D. D., \& Peterson, T. O. (1994). Contemporary management (3rd ed.). Boston: Houghton Mifflin.

Von Simson, E. M. (1990). The 'centrally decentralized' IS organization. Harvard Business Review, 68(4), 158-162.

Wagner, J. A., II, \& Van Dyne, L. (1999). The large introductory class as an exercise in organization design. Journal of Management Education, 23(2), 123-142.

Wulf, J. (2012). The flattened firm. California Management Review, 55(1), 5-23.

Zahra, S. A., Hayton, J. C., \& Salvato, C. (2004). Entrepreneurship in family vs. non-family firms: a resource-based analysis of the effect of organizational culture. Entrepreneurship Theory and Practice, 28(4), 363-381. 